\title{
Comparison of the Academic Performance of Students from Intact Homes and Broken Homes in Colleges of Agriculture and Related Disciplines in Plateau State, Nigeria
}

\author{
Michael Adejare Adegboye ${ }^{1, *}$, Esther Honotina Adegboye ${ }^{2}$ \\ ${ }^{1}$ Department of Extension and Management, Federal College of Land Resources Technology, Kuru, Nigeria \\ ${ }^{2}$ Department of Students' Affairs/Counselling, Federal College of Animal Health and Production Technology, Vom, Nigeria \\ Email address: \\ maadegboye@yahoo.com (M. A. Adegboye), etadegboye@yahoo.com (E. H. Adegboye) \\ ${ }^{*}$ Corresponding author
}

To cite this article:

Michael Adejare Adegboye, Esther Honotina Adegboye. Comparison of the Academic Performance of Students from Intact Homes and Broken Homes in Colleges of Agriculture and Related Disciplines in Plateau State, Nigeria. Advances in Applied Sciences.

Vol. 6, No. 2, 2021, pp. 19-26. doi: 10.11648/j.aas.20210602.13

Received: September 22, 2020; Accepted: October 9, 2020; Published: May 20, 2021

\begin{abstract}
College of agriculture and related disciplines have the mandate to train middle level manpower for agricultural sector making them appropriate for producing qualified extension agents. Academic performance, which has been confirmed by research to be determined among other factors by home status is the measure of the qualification in school training. Therefore, this study was designed to compare the academic performance of students from intact homes and broken homes in colleges of agriculture and related disciplines in Plateau state, Nigeria. It was discovered that $80.8 \%$ of the respondents were between the ages 18 and 26 years, both male and female were of equal percentage $(50.0 \%)$ and $82.5 \%$ single. Also, $58.3 \%$ of the respondents were children from intact homes with $62.5 \%$ having sibling from different mother, $84.2 \%$ having from different father, $60.0 \%$ of their mothers were the only wife, $83.3 \%$ had their parents living together, $68.3 \%$ had fathers still alive and $88.3 \%$ had mothers still alive. Majority (67.5\%) of the respondents were average and above in academic performance. However, $26.0 \%$ from broken homes had high performance against $22.9 \%$ from intact homes, $44.0 \%$ from broken homes had average against $42.9 \%$ from intact homes and $30.0 \%$ from broken homes were low compared with $34.3 \%$ from intact homes. There was a significant relationship between age $\left(\chi^{2}=24.417, p=0.000\right)$, marital status $\left(\chi^{2}=135.050, p=0.000\right)$, of the respondents and academic performance. Similarly, significant relationship existed between mother's position among fathers' wives $\left(\chi^{2}=7.5000, p=0.000\right)$, having siblings from different mother $\left(\chi^{2}=24.417, \mathrm{p}=0.000\right)$, having siblings from different father $\left(\chi^{2}=56.333, \mathrm{p}=0.000\right)$, parents living together $\left(\chi^{2}=53.333, p=0.000\right)$, fathers still alive $\left(\chi^{2}=16.133, p=0.000\right)$, mothers still alive $\left(\chi^{2}=70.533, p=0.000\right)$ of the respondents and academic performance. There is no significant relationship between respondents' home status and academic performance $(r=0.017, p=0.857)$. Also no significant difference between the academic performances of students from intact home and those from broken home $(\mathrm{t}=0.153, \mathrm{p}=0.000)$. Most of the respondents came from intact homes and the percentages of respondents with average performance and those with high performance from broken homes were higher than those of respondents from intact homes. However, no significant difference existed between the academic performances of students from intact home and those from broken home.
\end{abstract}

Keywords: Comparison, Academic Performance, Broken Home, Intact Home and College of Agriculture

\section{Introduction}

\subsection{Background of the Study}

Agriculture is an important sector of economy, which supplies basic necessity of life. Food in the form of plant and animal products is one of the first necessities of life and this is made available through agriculture $[1,2]$. It is not only man that benefits food from agriculture, feed for animals are obtained from agriculture. [3] noted that different industries came about as a result of technological development. We have textile industries, shoe industries and paper industries among 
others. All these industries get their raw materials from agriculture. Also, agriculture is a reliable source of foreign earning. Nigeria economy is still influenced by agriculture despite the discovery of crude oil and rapid industrial development [1]. There is no doubt that agriculture is fundamental to the sustenance of life.

With the visible importance of agriculture, its development becomes a thing of necessity. Agricultural development was described by $[4,5]$ as an effective strategy for economic development. [6], noticed that agricultural development is an integral part of economic development and has since been recognised as vital to poverty reduction and sustainable development. The focus of production development is improved yield, both in crops and animal farming enterprises. Improved yield result to improved income, which leads to improved standard of living. The agricultural development is made possible through effective extension system.

Effective extension is a function of favourable condition for extension operation and more importantly qualified extension personnel. Qualified extension personnels are those with relevant training to disseminate agricultural information appropriately towards agricultural and rural development. It is, however, worthy of note that academic performance, which has been confirmed by research to be determined among other factors by home status is the measure of the qualification in school training.

Effect of home status on academic performance has been reported by many researchers. Even when controlling for economic and racial differences of the family, children from two-parent households outperform children from one-parent households across a variety of measures [7-9] identified school dropout, truancy, teenage pregnancy and drug addiction as some of the problems faced by children from broken homes. Similarly, [10] identified educational problems; emotional problems; social, behaviour and learning difficulties as some of the broken home problems.

\subsection{Statement of the Problem}

College of agriculture and related disciplines are the appropriate institutions for producing required extension agents for agricultural information dissemination to farmers. [11] noted that of all the higher institutions of learning in Nigeria, colleges of agriculture and related discipline are known for training people for agricultural practices in different aspect ranging from production, education and marketing. They are the institutions with mandate to train middle level manpower in different areas of agricultural sector. Their curriculum is so designed in such a way that students undergo adequate practical by which they are well fitted for field work after training.

The most commonly accepted way of determining the quality of the trained personnel is the academic performance while in school. Academic performance is the outcome of education. It is the extent to which a student, teacher or institution has achieved their educational goals. In Nigeria, education is examination oriented and hence the only evaluation for performance is through examinations [12].
Academic achievement is commonly measured by examinations or continuous assessment but there is no general agreement on how it is best tested or which aspects are most important; procedural knowledge such as skills or declarative knowledge such as facts [13].

Family structure is one of the most researched and debated factor among education professionals, psychologists and sociologists that contribute towards the academic performance of students [14]. Many studies have documented the challenges faced by single parents and the disadvantages of their children relative to children raised in two-parent households [15]. The most prevalent argument is that family structure (home status) of learners affects the quality of their academic performance. Those studies mainly found a negative relationship between non-nuclear family structures and child outcomes [15]. Life in a broken home can be stressful for both the child and the parent as such families are faced with challenges of inadequate financial resources [16]. Therefore, this study was designed to compare the academic performance of students from intact homes and broken homes in colleges of agriculture and related disciplines in Plateau state, Nigeria. Then the following questions were asked in pursuit of the study's major objective.

(i) What are the personal characteristics of the students in the study area?

(ii) What is the home status of the students in the college of agriculture and related disciplines in Plateau state?

(iii) What is the academic performance of students from broken homes and those from intact homes?

\subsection{Specific Objectives of the Study}

The specific objectives of the study are to:

(i) determine the personal characteristics of the students

(ii) determine the home status of the students in the college of agriculture and related disciplines in Plateau state

(iii) find out the academic performance of students from broken home and those from intact home.

\subsection{Hypothesis of the Study}

The following null hypotheses were considered for the study:

(i) There is no significant relationship between selected respondent's personal characteristics and the academic performance.

(ii) There is no significant relationship between the respondents' home status and academic performance.

(iii)There is no significant difference between the

(iv)academic performances of students from intact home and those in broken home.

\section{Methodology}

\subsection{The Study Area}

Plateau State is one of the states in the north central geopolitical zone of Nigeria. It is located between latitudes $7^{\circ}$ and $11^{\circ} \mathrm{N}$, and longitudes $7^{\circ}$ and $25^{\circ} \mathrm{E}$ [17]. The state shares 
boundary with Bauchi State to the north, Taraba to the east/southeast, Nasarawa to southwest and Kaduna State to the northwest. Plateau State derived its name from the geographical landscape that predominates in this part of the country which is referred to as the Jos plateau. Plateau State has an area of 26,898 square kilometers and population figure of 3,206,531 [18]. The Jos Plateau has been inhabited since the Acheulean period of the Early African Stone Age, as shown by the hand axes found near Jos town.

The plateau is inhabited by many different ethnic groups, of which the Berom is the largest, and the best known [19]. Others include Jarawa, Rukuba, Irigwe and Sura apart from settlers from other parts of Nigeria and outside Nigeria. Population on the plateau is predominantly rural and most of the inhabitants live in small villages and surrounded by cactus hedges of Euphorbia kamerunica. These people were traditionally subsistence farmers, and despite the advent of tin mining in 1904, relatively few people have been attracted to the mines.

\subsection{Sampling Techniques}

Multistage sampling technique was used for the study. Simple random sampling was used to select three of the five Colleges in the Plateau State. Simple random sampling was also used to select four departments from each of the sampled College. From each of the departments, ten respondents were selected for interview by systematic random sampling. Altogether, a total of one hundred and twenty (120) respondents were used in the study.

\subsection{Measurement of Variables}

Section A: Personal characteristics

1. Age: Respondents were asked to state their age in years

2. Sex: Respondents were asked to indicate their sex from the options (a) Male (b) Female

3. Marital status: Respondents were asked to indicate whether single, married, divorced or widow

Section B: Information relating to broken home

4. Mother's position among father's wives: Respondents were asked to indicate their mother's position from the options (a) The only wife (b) First wife (c) Second wife (d) Third wife

(e) Others (specify) After data entry, (a) was scored

1 and all other options taken to be only one and scored 0

5. Any brother or sister from the same father but different mother: The respondents were asked through Yes or No whether they have brother(s) or sister(s) from same father but different mother. After data entry, (a) was scored 0 and (b) scored 1

6. Any brother or sister from the same mother but different father: The respondents were asked through Yes or No whether they have brother(s) or sister(s) from same mother but different father. After data entry, (a) was scored 0 and (b) scored 1

7. Parents living together: Respondents were asked through Yes or No whether their parents are living together. After data entry, (a) was scored 1 and (b) scored 0
8. Father still alive: Respondents were asked through Yes or No whether their fathers are still alive. After data entry, (a) was scored 1 and (b) scored 0

9. Mother still alive: Respondents were asked through Yes or No whether their mothers are still alive. After data entry, (a) was scored 1 and (b) scored 0

Scores for items 6 to 11 were summed up. Lowest score and highest score were determined and used to find the mean score. Scores below mean indicate the broken home while mean and above indicate intact home.

Section C: Information relating to academic performance

10. Academic performance: Academic performance was measured by cumulative grade point average (CGPA) as an approximation of academic performance which is calculated by the average of all respondents' coursework grades over one year [20]. In Colleges of Agriculture and related disciplines, the pass CGPA rages from 2.0 to 3.5 and above for both ND and HND (table 1). From the table, any score below 2.50 was taken to be low performance, $2.50-2.99$ average and above 3.00 high performance.

Table 1. The CGPA and the class of Diploma in Colleges of Agriculture and related disciplines.

\begin{tabular}{ll}
\hline CGPA & CLASS OF DIPLOMA \\
\hline 3.50 and above & Distinction \\
$3.00-3.49$ & Upper Credit \\
$2.50-2.99$ & Lower Credit \\
$2.00-2.49$ & Pass \\
Below 2.00 & Fail \\
\hline
\end{tabular}

Source: [21]

\subsection{Method of Data Analysis}

Data obtained from the study were coded and subjected to descriptive statistics such as frequency and percentage distribution. Chi-square $\left(\chi^{2}\right)$ was used to determine the relationship between personal characteristics and academic performance, Pearson's Product Moment Correlation (PPMC) was employed to find out the significant relationship between the respondent's home status and academic performance. Similarly, t-test was used to determine the difference between the academic performances of students from intact home and those in broken home.

\section{Results and Discussion}

\subsection{Personal Characteristics of Respondents}

\subsubsection{Age}

Table 2 shows that $80.8 \%$ of the respondents were between the ages 18 and 26 years. Only $7.5 \%$ of the respondents were within $27-29$ years while $11.7 \%$ were 30 years and above. The finding is in tandem with the observation of [22] that majority $59.6 \%$ of the students were 20 - 25 years of age. However, the result is different from the report of [11] that majority of the students $(51.25 \%)$ were $25-29$ years. This gives an indication that students in colleges of agriculture now are younger in age than those of 2008 . 


\subsubsection{Sex}

Also, Table 2 reveals that both male and female are of equal percentage $(50.0 \%)$. This result is different from the observation of [11] which was $75.0 \%$ and $25.0 \%$ for male and female. From the result, there is an indication that a drastic improvement has occurred in girl child education in Plateau state.

\subsubsection{Marital Status}

Table 2 shows that $82.5 \%$ of the respondents were single while $16.7 \%$ were married. Marriage is a responsibility that can affect concentration in learning. Hence it is in order as majority of the students were single. In the study of [11], $63.8 \%$ were single while $36.2 \%$ were married. Comparing the results of the two studies, one will discover that less percentage of students were married in this study. This might be due to the fact that more of the students now are younger than those in 2008.

Table 2. Personal characteristics of respondents.

\begin{tabular}{lll}
\hline Variables & Frequency & Percentage \\
\hline Age (years) & & \\
$18-20$ & 28 & 23.3 \\
$21-23$ & 43 & 35.8 \\
$24-26$ & 26 & 21.7 \\
$27-29$ & 9 & 7.5 \\
30 years and above & 14 & 11.7 \\
Sex & & \\
Male & 60 & 50.0 \\
Female & 60 & 50.0 \\
Marital Status & & \\
Single & 99 & 82.5 \\
Married & 20 & 16.7 \\
Separated & 1 & 0.8 \\
\hline
\end{tabular}

Source: Field survey (2020)

\subsection{Respondents' Home Status}

\subsubsection{Respondents' Mother's Position Among Wives}

As can be seen in table 3,60.0\% were the only wives of their husbands, $25.8 \%$ first wives, $11.7 \%$ second wives. Only $1.7 \%$ and $0.8 \%$ were third and fourth wives respectively. Children in polygamous marriages may face abuse, psychological distress, low self-esteem, and marital discord [23]. According to [24] the frequent marital conflict and distress can cause emotional harm to the children through conflict, tension, unequal treatment by the polygamous father and jealousy. These children frequently feel discontented with their families [23]. They are often unable to receive the necessary emotional support from their father in particular. According to [23], discontent with the family often increases with the addition of wives by the father.

\subsubsection{Siblings from Different Mother But Same Father}

Table 3 shows that $62.5 \%$ of the respondents did not have sibling from different mother while $37.5 \%$ indicated that they had siblings from different mother but the same father. Having siblings from different mother is an indication that the respondents came from a polygamous family and more children that may not get proper fathers' attention. Culturally, polygamy is viewed as a reproductive strategy by which men maximize the number of their offspring but minimize investment in each child [23]. However, majority of the respondents had their siblings from the same father and mother; and are expected to enjoy their fathers' attention.

\subsubsection{Siblings from Different Father But Same Mother}

Table 3 shows that $84.2 \%$ of the respondents did not have sibling from different father while $15.8 \%$ indicated that they had siblings of the same mother but different father. It is possible to have siblings from different father but the same mother as a result of a woman having a child before marriage or a child from previous marriage. The children from the new marriage may have behavioural problems. However [25] noted that adolescents had fewer behaviour problems if there is a positive relationship not only with biological parents, but if stepparents are involved, especially a strong relationship with stepfathers [25]. Since most of the respondents did not have siblings from different father, they were not expected to have such emotional problems that would affect their performance negatively.

\subsubsection{Respondents' Parents Living Together}

Also, Table 3 shows that $83.3 \%$ of the respondents indicated that their parents were living together while $16.7 \%$ indicated that their parents were not together. Non-living together of parents is an indication of separation which is a feature of broken home. In case of divorce, separation or death of a parent, children are at somewhat greater risk for symptoms of poor psychological adjustment, behavioural and social problems, low self-esteem and poor performance in school. [7] found that most medical students whose fathers had been absent while they were at ages one to five of life were more psychiatric, psychopathic and criminalistics in nature than those whose parents were present during this period. According to [7], a child from intact homes will be well taken care of and well socialised as possible. This is due to the fact that the process of socialization depends on both parents playing complementary roles in bringing up the child. In this study, majority of the respondents had their parents living together. Hence, they are expected to be free from poor psychological adjustment, behavioural and social problems, low self-esteem and poor performance in school affecting children from broken homes.

\subsubsection{Respondents' Fathers Still Alive}

As revealed in table 3, majority of the respondents $68.3 \%$ indicated that their fathers were still alive while $31.7 \%$ have lost their father. It is a great blessing for any child to enjoy father's relationship that has high possibility of total development of the child. If a child's father is affectionate, supportive, and involved, he can contribute greatly to the child's cognitive, language, and social development, as well as academic achievement, a strong inner core resource, sense of well-being, good self-esteem, and authenticity [26]. According to [26] a child's primary relationship with his/her father can affect all of his/her relationships from birth to death, including those with friends, lovers, and spouses. For majority of the respondents' fathers still alive, it means they have the opportunity of still enjoying the mentorship of their fathers. 


\subsubsection{Respondents' Mother Still Alive}

Table 3 shows that majority $88.3 \%$ of the respondents indicated that their mothers were still alive. Only $11.7 \%$ of the respondents had lost their mothers. The role of a mother is unique in any home. She understands what a child does not say. Mothers can hear sentences in the silences of their children. According to [27], God has given mothers the special gift of intuition because it gives her a strong sense of what is right for her children, what they are good at, how they may excel in the future what gifts and abilities she needs to make sure are developed in their lives as God intended. Mothers are timeless teachers in the classroom of life and most influential educators [27]. As majority of the respondents still had their mothers alive, there is an opportunity for them to be enjoying love, compassion and guidance from their homes.

Table 3. Respondents' home status.

\begin{tabular}{lll}
\hline Variables & Frequency & Percentage \\
\hline Respondents mother's position among wives & & \\
The only wife & 72 & 60.0 \\
First wife & 31 & 25.8 \\
Second wife & 14 & 11.7 \\
Third wife & 2 & 1.7 \\
Fourth wife & 1 & 0.8 \\
Siblings from different mother but same father & & \\
Yes & 45 & 37.5 \\
No & 75 & 62.5 \\
Siblings from different father but same mother & & \\
Yes & 19 & 15.8 \\
No & 101 & 84.2 \\
Respondents' parents living together & & \\
Yes & 100 & 83.3 \\
No & 20 & 16.7 \\
Respondents' father still alive & & \\
Yes & 106 & 68.3 \\
No & 38 & 31.7 \\
Respondents' mother still alive & & \\
Yes & & \\
No & & \\
\hline & & \\
\hline
\end{tabular}

Source: Field survey (2020)

\subsubsection{Home Status Categories}

Table 4 reveals that $58.3 \%$ of the respondents were children from intact homes while $41.7 \%$ came from broken home. Home status is an important factor affecting the life of children even to adulthood. [28] indicated that children from broken homes are at greater risk for symptoms of poor psychological adjustment, behavioural and social problems; low self-esteem; school dropout rates; tearful or depressed; poverty and poor performance in schools. However, children with two parents show higher academic achievement at lower school [29], have lower dropout rates [30], and higher college enrolment rates [31] than other children. The result of this study reveals that the students were from intact home. Consequently, they are not supposed to suffer many of those Psychological and social problems of broke home.
Table 4. Home status categories

\begin{tabular}{llll}
\hline Home status categories & Score range & Frequency & Percentage \\
\hline Broken & $1-4.4$ & 50 & 41.7 \\
Intact & $4.5-6.0$ & 70 & 58.3 \\
Total & $1-6$ & 120 & 100.0 \\
\hline
\end{tabular}

Mean $=4.5 \pm 1.5$

Source: Field survey, 2020

\subsection{Academic Performance Information}

\subsubsection{Number of Course Failed in Year 1 by Respondents}

Result of the number of course failed by the respondents in year 1 is presented in table 5 . The table shows that $56.6 \%$ passed all courses taken, $17.5 \%$ failed only one course, $9.2 \%$ failed two courses, $7.5 \%$ failed three, $5.0 \%$ failed four, $2.5 \%$ failed five and $1.7 \%$ failed more than five courses in year 1 . The study reveals that the respondents' performance generally was not bad in their first year. From $32.0 \%$ of the respondents that failed at least 1 course, $20.0 \%$ of those from broken homes failed 3 courses and above against $14.3 \%$ from intact homes. The study reveals that the respondents' performance generally was not bad in their first year. From $32.0 \%$ of the respondents that failed at least 1 course, $20.0 \%$ of those from broken homes failed 3 courses and above against $14.3 \%$ from intact homes. This is in line with the assertion that children from intact homes perform better than their counterparts from broken homes.

Table 5. Number of course failed in year 1 by respondents.

\begin{tabular}{llll}
\hline $\begin{array}{l}\text { Number of } \\
\text { course failed }\end{array}$ & Home status & \multicolumn{2}{c}{ Total } \\
\cline { 2 - 3 } & Broken (1-4.4) & Intact (4.5-6) & \\
\hline 0 & $28(56.0)$ & $40(57.1)$ & $68(56.6)$ \\
1 & $8(16.0)$ & $13(18.6)$ & $21(17.5)$ \\
2 & $4(8.0)$ & $7(10.0)$ & $11(9.2)$ \\
3 & $4(8.0)$ & $5(7.1)$ & $9(7.5)$ \\
4 & $3(6.0)$ & $3(4.3)$ & $6(5.0)$ \\
$>4$ & $3(6.0)$ & $2(2.9)$ & $5(4.2)$ \\
Total & $50(100.0)$ & $70(100.0)$ & $120(100.0$ \\
\hline
\end{tabular}

*Percentage in parenthesis

Source: Field survey, 2020

\subsubsection{Respondents' Diploma Classification}

Classification of the respondents' result is shown in table 6 . The table reveals that $43 \%$ of the respondents had lower credit, $25.8 \%$ had pass, $19.2 \%$ had upper credit, $6.8 \%$ failed while $5.0 \%$ had distinction. In summary, it means $93.2 \%$ of the respondents passed at the end of their first year in the Colleges; which is a better result. Though significantly un-conspicuous, the percentage of respondents from broken homes that failed was higher than those that failed in intact home. However, their percentages for lower credits, upper credits and distinctions were higher than those of respondents from intact homes. Considering the Diploma classification, the respondents from broken homes had better results than those from the intact home. This result is contrary to that of [32] that adults whose parents are divorced have lower educational performance. However, the result is similar to the observations of $[33,22]$ that there was no difference between the performance of the students from intact home and those 
from broken home.

Table 6. Respondents' Diploma classification.

\begin{tabular}{llll}
\hline Diploma class of & Home status & \\
\cline { 2 - 3 } respondents & $\begin{array}{l}\text { Broken }(\mathbf{1}- \\
\text { I.4) }\end{array}$ & $\begin{array}{l}\text { Intact (4.5- } \\
\text { 6) }\end{array}$ & \\
\hline Fail (Less than 2.00) & $5(10.0)^{*}$ & $3(4.3)^{*}$ & $8(6.8)$ \\
Pass $(2.00-2.49)$ & $10(20.0)$ & $21(30.0)$ & $31(25.8)$ \\
Lower credit $(2.5-2.99)$ & $22(44.0)$ & $30(42.9)$ & $52(43.3)$ \\
Upper credit $(3.00-3.49)$ & $10(20.0)$ & $13(18.6)$ & $23(19.2)$ \\
Distinction $(3.50$ and above) & $3(6.0)$ & $3(4.3)$ & $6(5.0)$ \\
Total & $50(100.0)$ & $70(100.0)$ & $120(100.0)$ \\
\hline
\end{tabular}

*Percentage in parenthesis

Source: Field survey, 2020

\subsubsection{Respondents'Academic Performance}

Academic performance of the respondents is revealed in table 7 . As shown in the table, $43.3 \%$ of the respondents had average performance, $32.5 \%$ had low and $24.2 \%$ had high academic performance. In summary, the academic performance of the respondents was less than $70 \%$. Majority of the respondents had average academic performance. However, 26.0\% from broken homes had high performance against $22.9 \%$ from intact homes, $44.0 \%$ from broken homes had average against $42.9 \%$ from intact homes and $30.0 \%$ from broken homes were low compared with $34.3 \%$ from intact homes. Considering this result, the respondents from broken homes had slightly better academic performance than those from the intact home. This result is different from the discovery of [32] that adults whose parents are divorced have lower educational performance. However, the result is similar to the observations of $[33,22]$ that there was no difference between the performance of the students from intact home and those from broken home. The slight better performance of respondents from broken home than those from intact home might be due to the fact that many homes today are intact but not happy. In that case, the children from broken home with happiness may perform better.

Table 7. Respondents' academic performance.

\begin{tabular}{llll}
\hline $\begin{array}{l}\text { Respondents' } \\
\text { academic }\end{array}$ & \multicolumn{2}{l}{ Home status } & \\
\cline { 2 - 3 } performance & $\begin{array}{l}\text { Broken }(1- \\
\text { T.4) }\end{array}$ & $\begin{array}{l}\text { Intact }(\mathbf{4 . 5} \\
\text { Total }\end{array}$ & \\
\hline Low (Below 2.50) & $15(30.0)^{*}$ & $24(34.3)^{*}$ & $39(32.5)$ \\
Average $(2.5-2.99)$ & $22(44.0)$ & $30(42.9)$ & $52(43.3)$ \\
High (3.00 and above) & $13(26.0)$ & $16(22.9)$ & $29(24.2)$ \\
Total & $50(100.0)$ & $70(100.0)$ & $120(100.0)$ \\
\hline
\end{tabular}

*Percentage in parenthesis

Source: Field survey, 2020

\subsection{Hypothesis Testing}

\subsubsection{Hypothesis 1}

The hypothesis seeks to test for relationship between selected personal characteristics and academic performance of the respondents. Chi square $\left(\chi^{2}\right)$ was used to test the hypothesis. The results in table 8 show significant relationship between age $\left(\chi^{2}=24.417, \mathrm{p}=0.000\right)$, marital status $\left(\chi^{2}=\right.$ $135.050, p=0.000)$ of the respondents and their academic performance. Similarly, significant relationship existed between mother's position among fathers' wives $\left(\chi^{2}=7.5000\right.$, $\mathrm{p}=0.000)$, having siblings from different mother $\left(\chi^{2}=24.417\right.$, $\mathrm{p}=0.000)$, having siblings from different father $\left(\chi^{2}=56.333\right.$, $\mathrm{p}=0.000)$, parents living together $\left(\chi^{2}=53.333, \mathrm{p}=0.000\right)$, fathers still alive $\left(\chi^{2}=16.133, \mathrm{p}=0.000\right)$, mothers still alive $\left(\chi^{2}=70.533, p=0.000\right)$ of the respondents and their academic performance.

Significance shown by mother's position among fathers' wives, having siblings from different mother, having siblings from different father, parents living together, fathers still alive and mothers still alive, which are features of broken home confirms that broken home has relationship with academic performance. This is in line with the discovery of [28] that children from broken homes are at greater risk for symptoms of poor psychological adjustment, behavioural and social problems; low self-esteem; school dropout rates; tearful or depressed; poverty and poor performance in schools. Two-parent families invest more in educational resources and showing more family involvement, making their children performance be better [14].

Table 8. Relationship between personal characteristics and academic performance of respondents using $\chi^{2}$.

\begin{tabular}{lllll}
\hline Variables & Df & $\chi^{2}$ Cal. & p-value & Decision \\
\hline Age & 4 & $24.417^{*}$ & 0.000 & Significant \\
Sex & 1 & $0.000^{\wedge}$ & 1.000 & Not significant \\
Marital status & 2 & $135.050^{*}$ & 0.000 & Significant \\
Mothers' position among wives & 4 & $144.417^{*}$ & 0.000 & Significant \\
Sibling(s) from different mother & 1 & $7.500^{*}$ & 0.000 & Significant \\
Sibling(s) from different father & 1 & $56.033^{*}$ & 0.000 & Significant \\
Parents living together & 1 & $53.333^{*}$ & 0.000 & Significant \\
Fathers still alive & 1 & $16.133^{*}$ & 0.000 & Significant \\
Mothers still alive & 1 & $70.533^{*}$ & 0.000 & Significant \\
\hline
\end{tabular}

Df $=$ Degree of freedom

$\chi^{2}=$ Chi-square

$\mathrm{p}=$ Probability level

*Chi-square is significant at $\mathrm{p}<0.05$

${ }^{\wedge}$ Chi-square is not significant at $\mathrm{p}<0.05$

Source: Field survey (2020)

\subsubsection{Hypothesis 2}

The hypothesis seeks to test for relationship between the respondent's home status and academic performance. Pearson's Product Moment Correlation (PPMC) was used to test the hypothesis.

The results in table 9 show that there is no significant relationship between respondents' home status and academic performance at $r$-value of $0.017,(p=0.857)$. Hence, the null hypothesis is accepted. This result is different from the observation of $[8,32]$ that children from intact homes outperform children from broken homes and adults whose parents are divorced have lower educational attainment. However, the finding of this study is in line with the discovery of $[33,22]$ that there was no difference between the performance of the students from intact home and those from broken home. 
Table 9. Relationship between home status and academic performance using PPMC.

\begin{tabular}{lllll}
\hline Variables & N & r-value & p-value & Decision \\
\hline $\begin{array}{l}\text { Home status } \\
\text { Academic performance }\end{array}$ & 120 & 0.017 & 0.857 & $\begin{array}{l}\text { Not } \\
\text { significant }\end{array}$ \\
\hline
\end{tabular}

Correlation is not significant at 0.05 levels (2tailed)

Source: Field survey (2020)

\subsubsection{Hypothesis 3}

The hypothesis seeks to test for difference between the academic performances of students from intact home and those from broken home. The statistical used for the hypothesis was t-test.

The results in the table 10 shows that there is no difference between the academic performances of students from intact home and those from broken home at t-value of 0.153 , ( $p=$ 0.000 ). Hence, the null hypothesis is accepted. This result is at variance with the assumptions of $[34,35,32]$ that adults whose parents are divorced have lower educational attainment. According to [14] two-parent families invest more in educational resources and showing more family involvement, making their children performance be better. However, the finding of this study is in tandem with the discovery of $[36,33,22]$ that there was no difference between the performance of the students from intact home and those from broken home. This is an indication that coming from a broken home may not necessarily cause students to perform poorer than their counterparts from intact homes especially in tertiary institutions. Children with two parents show higher academic achievement at lower school [29], have lower dropout rates [30], and higher college enrolment rates [31] than other children. This means that many of the children from broken home would have dropped out of school and not get to tertiary institutions. Only those without negative effect of broken home on them would be able to proceed to tertiary institutions. This may be the reason why majority (58.3\%) of the respondents in this study were from intact home. Consequently, there could not be difference between the academic performance of those from intact and broken homes.

Table 10. Difference between the academic performances of students from intact home and those from broken home using t-test.

\begin{tabular}{llll}
\hline Variables & Df & t-value & p-value \\
\hline $\begin{array}{l}\text { Performance of students from intact home } \\
\text { Performance of students from broken home }\end{array}$ & 118 & $0.153^{\wedge}$ & 0.209 \\
\hline
\end{tabular}

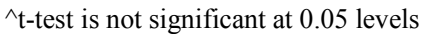

Source: Field survey (2020)

\section{Conclusion}

Most of the respondents indicated that their mothers were the only wife of their father. They did not have siblings from either different fathers or mothers. Their parents were living together and their fathers and mothers were still alive. Most of the respondents came from intact homes and the percentage of those that failed 3 courses and above were more from broken homes than the intact homes. However, their percentages for lower credits, upper credits and distinctions were higher than those of respondents from intact homes. Percentages of respondents with average performance and high performance from broken homes were higher than those of respondents from intact homes. Significant relationship existed mother's position among fathers' wives, having siblings from different mother, having siblings from different father, parents living together, fathers still alive, mothers still alive of the respondents and their academic performance. However, no significant difference existed between the academic performances of students from intact home and those from broken home.

\section{References}

[1] Ugwu, D. S. and Kanu, I. O. (2012). Effects of Agricultural Reforms on the Agricultural Sector in Nigeria. Journal of African Studies and Development 4 (2): 51-59.

[2] Adegboye, M. A. 2009 Factors that determine the selection of agricultural science by SS III students in Jos south local government area. Journal of Educational Studies 14 (1): 65-71.

[3] Adegboye, M. A. (2016). Effect of Participation in Community-based Agriculture and Rural Development Project on Socio-economic Status of Rural Dwellers in Northern Nigeria. Asian journal of Agricultural Extension, Economics and Sociology 9 (3): 1-13. Available online at www.sciencedomain.org

[4] Olojede, J. C. And Chinaka, C. C. (2006) Participation of Abia State women farmers in Agricultural Extension Communication Activities. Proceedings of the $40^{\text {th }}$ Annual Conference of Agricultural Society of Nigeria (ASN) held at National Root Crop Research Institute, Umudike, Abia State, Nigeria. October 16-20, 2006: 256-260.

[5] Abubakar, L. and H. A. Abdullahi (2009) Information and agricultural development in Nigeria: Challenges and opportunities. Proceedings of the 43rd Annual Conference of Agricultural Society of Nigeria (ASN) held at National University Commission and Raw Materials Research and Development Council, Abuja Nigeria. October 20-23, 2009: 715-717.

[6] Eluagu, I. L. (2006) Status of the farmers-students linkage system in the diffusion of yam minisett technology in Ishiagu Ebonyi state. Proceedings of the $40^{\text {th }}$ Annual Conference of Agricultural Society of Nigeria (ASN) held at National Root Crop Research Institute, Umudike, Abia State, Nigeria. October 16-20, 2006: 311-314.

[7] Downey, D. (1994). The school performance of children from single mother and single father families: Economic or interpersonal deprivation? Journal of family issues, 15: 129-147.

[8] Kim, E. (2002). The relationship between parental involvement and children's educational achievement in the Korean immigrant family. Journal of Comparative Family Studies. 33: $529-540$.

[9] Nyarko, K. (2011). Parental School Involvement: The Case Of Ghana. Journal Of Emerging Trends In Educational Research And Policy Studies, 2 (5): 378-381. 
[10] Frank, K. (2012). The influence of Broken Homes on pupil. Academic performance is selected schools in Mbala District: Lessons for School Managers. (Unpublished M. Ed. Project). University of Zambia.

[11] Adegboye and Jonah (2008). Determinants of the choice of agriculture by the students of colleges of agriculture and related disciplines in Plateau state. Proceeding of the $42^{\text {nd }}$ annual conference of Agricultural Society of Nigeria (ASN) held $19^{\text {th }}$ $-23^{\text {rd }}$ October 2008 at Ebonyi state University, Abakaliki, Nigeria. P. 830-834.

[12] Centre for American Progress (CAP) (2012). How to Measure Academic Achievement. Accessed 27 December, 2019. Available:

http://www.big.comlhow-5517492-measure-academic-achieve ment.hml.

[13] Oyewole, O. J. (nd). Influence of parental socioeconomic status on student's academic performance in senior secondary school Mathematics in Ila-Local Government Area of Osun State. B. Ed. degree project in the Department of Mathematics, University of Uyo. Available: https://independent.academia.edu

[14] Refu, A.; Getahun, E. and Shiferaw, G. (2017). Family structure and child victimization as predictors of children's academic achievement in primary schools of Ilubabora zone. Int. J. Adv. Res. 5 (10), 522-544. Accessed 17 December, 2019. Available: www.journalijar.com.

[15] Mandara, J. amd Murray, C. (2006). Father's absence and African American adolescent drug use. Journal of divorce and remarriage, $64,1-12$.

[16] Azubuike, C. (2015). Family structure, Parental practices and High School: Awake completion; American Sociological Review. 5 (3): 318-319.

[17] Plateau State Government (P.S.G.) (1987). Hand book on Plateau State. A general overview. Jos, Nigeria: Department of information, Internal Affairs, Protocol and Printing, Jos in Collaboration with the ministerial committee on first Jos International Trade Fair \% Ministry of Trade and Co-operative, Jos Plateau state. P. 1-9.

[18] National Population Commission of Nigeria (NPCN) (2006). Population and Housing Census Facts and Figures. Accessed 17 December, $2019 . \quad$ Available: http://www.population.gov.ng/factsandfigures2006.html.

[19] Gwom, S. L. (1992). The Berom Tribe of Plateau State of Nigeria. Jos Nigeria: Fab Anieh (Nigeria) Limited. 64-65.

[20] Esmaeili, N. S. and Yaacob, S. N. (2013). Post-divorce Parental Conflict, Maternal Economic Hardship, Parent-child Relationship and Academic Achievement among Adolescents in Divorced Families, Jokull Journal 63 (8): 110-122.

[21] National Board for Technical Education (NBTE) (1989). National Diploma (ND) Agricultural Technology. Curriculum and course specifications $4 p$.

[22] Jaiyeola, A. H. O. and Akinjide, A. K. (2016). Effect of single parenthood factors on the academic performance of undergraduate medical students of the college of medicine, university of Ibadan, Nigeria. International Journal of Social Sciences and Humanities Reviews. 6 (1): 57-67.

[23] Chikwature, W. and Oyedele, V. (2016). Polygamy and academic achievement-a case of Johanne Marange Apostolic sect. European Journal of Research in Social Sciences 4 (5): $1-5$.

[24] Elbedour, S., Onwuegbuzie, A. J., Caridine, C., \& Abu-Saad, H. (2002). The effect of polygamous marital structure on behavioral, emotional, and academic adjustment in children: A comprehensive review of the literature. Clinical Child and Family Psychology Review, 5, 255-271.

[25] Ogungbesan, S. A. (2018). Effects of parents' proficiency in English on the performance of Secondary School Students in English Language Examination. Unpublished B. A. degree project in the Department of English Language, Faculty of Arts, National Open University of Nigeria, Abeokuta Study Centre, Abeokuta, Ogun State.

[26] Gross, G. (2014). The important role of Dad. Accessed 7 December, $2019 . \quad$ Available: https://www.huffpost.com/entry/the-important -role-of-dad b 5489093.

[27] Avarientos, N. (2017). Being a mother: An important role of a woman. World vision. Accessed 11 January, 2020. Available: https://www.worldvision.org.ph/stories/being-a-mother-an-im portant-role-of-a-woman/.

[28] Chinh, S. and Tabata, Y. (2003). Teacher factors and mathematics achievement of Cambodian Urban primary school pupils. Journal of International Development and Cooperation, 9 (2): $29-41$.

[29] Cherlin, A. J., and Furstenberg, F. F. (1994). Stepfamilies in the United States: A reconsideration. In: Blake, J. and Hagan, J. (Eds.), Annual Review of Sociology (pp. 359-381). Palo Alto, CA: Annual Reviews.

[30] Kiernan, K. E. (1992). The impact of family disruption in childhood on transition made in young adult life. Population Studies, 46, 213-234.

[31] Beller, A. H., and Chung, S. S. (1992). Family structure and educational attainment of children: Effects of remarriage. Journal of Population Economics, 5, 39-59.

[32] Uwaifo, V. O. (2008). The effects of family structure and parenthood on the academic performance of Nigerian University Students. Stud Home Comm Sci, 2 (2): 121-124.

[33] Ogbeide, F; Odiase, I. and Omofuma, J. E (2013). Influence of Broken Homes on Secondary School Students' Academic Performance in Esan West Local Government 71 Area of Edo State, Nigeria. Journal of Sociology, Psychology and Anthropology in Practice, 5: $2 p$.

[34] Amato, P. R. and DeBoer, D. D. (2001). The transmission of marital instability across generations: Relationship skills or commitment to marriage? Journal of Marriage and Family 63 (4): 1038-1051.

[35] Ezewu, E. (1990). Sociology of Education. Low price edition. London, Longman. Accessed 14 November, 2019. Available: https://books.google.com.ng/books/about/Sociology_of_Educ ation.html.

[36] Marsh, H. W. (1990). Two-parent, Step Parent, and Single-parent Families: Changes in Achievement, Attitudes, and Behaviours During the Last Two Years of High School. Journal of Educational Psychology, 82 (2), 327-340. 